\title{
SOCIOECONOMIC DEVELOPOMENT ON POVERTY ALLEVIATION OF WOMEN ENTREPRENEURSHIP
}

ANik Syuhailah Nik Hussin, BZuraimi Abdul Aziz

\section{ARTICLE INFO}

\section{Article history:}

Received: 15 July 2021

Accepted: 27 October 2021

\section{Keywords:}

Women entrepreneurship, poverty allevaition, microfinance, entrepreneurial, socioeconomic.

\section{ABSTRACT}

Purpose: In many developing and affluent countries, poverty alleviation has been the prime goal of promoting socioeconomic status. The Government's attempt to curb poverty includes promoting monetary-generation projects, providing facilities to raise the standard of living, and executing the programs to teach positive values for these underprivileged. The research seeks to uncover decisive aspects of socioeconomic improvement of poverty alleviation in women entrepreneurship.

Methodology: Data of 300 women entrepreneurs from three different states in Malaysia participated in the study. We have analyzed the research data through PLS-SEM to examine the formulated hypotheses.

Findings: It indicates microfinance was the strongest predictor of poverty alleviation in Malaysia. Entrepreneurial and personality factors are next on the list. Conversely, the environment and culture had little impact on impoverishment

Research Implications: The importance a cceptance of the microfinance program is the primary catalyst in creating new employment. It also provides a source of earning to improve the underprivilege's social and economic well-being and eradicate poverty.

Doi: https://doi.org/10.26668/businessreview/2021.v6i1.283

A PhD from Universiti Malaysia Terengganu, Kuala Nerus (Malaysia). She is marketing lecturer at Universiti Malaysia Kelantan, Kelantan (Malaysia). Email: niksyuhailah@umk.edu.my Orcid:https://orcid.org/0000-0002-9055-6787

B PhD from Universiti Malaysia Kelantan, Kelantan (Malaysia). He is an associate professor at Universiti Malaysia Kelantan, Kelantan (Malaysia). Email: zuraimi@umk.edu.my Orcid: https://orcid.org/0000-0002-9426-0502 


\title{
DESARROLLO SOCIOECONÓMICO PARA LA PALIACIÓN DE LA POBREZA MEDIANTE EL EMPRENDIMIENTO DE LA MUJER
}

Propósito: En muchos países em vías de desarrollo y afluentes, la paliación de la pobrezaha sido la meta principal para el ascenso de estatus socioeconómico. El intento del gobierno de reducir la pobreza incluye promover proyectos que generan riqueza, proveer instalaciones para aumentar el nível de vida, y ejecutar programas para ensenar valores positivos a los más desfavorecidos. La investiga ción busca revelar a spectos decisivos de la mejora socioeconómica de la paliación de la pobreza mediante el emprendimiento de la mujer.

\begin{abstract}
Metodología: Se han recopila do los datos de 300 mujeres emprendedoras de tres esta dos distintos em Malasia, que han participado em el estúdio. Hemos analizado los datos de la investigación mediante PLS-SEM para examinar la hipótesis foemulada.
\end{abstract}

Conclusiones: Indica que la micro financiación fue el pronosticador más significativo de la paloación de la pobreza em Malasia. Los factores empresariales y de personalidad le siguen en la lista. Em cambio, elentomo y la cultura tuvieron poco impacto sobre elempobrecimento.

Implicaciones de la Investigación: La importância de la aceptación del programa de micro financiación es el principal cataliza dor en la creación de nuevo empleo. También provee una fuente de ingresos para mejorar el bien estar socialy económico de los más desfavorecidos y erra dicar la pobreza.

Palabras clave: Emprendimiento de Mujeres; Paliación de la Pobreza; Micro finanza; Empresarial; Socieconómico.

\section{INTRODUCTION}

Malaysia has auspiciously transitioned itself from an emerging country into a middle-income nation. Despite challenging external factors, the Malaysian economy has experienced periodic growth. It unquestionably claims its accomplishment in combat against poverty. The formulation of Malaysia's New Development and New Economic policy has placed a solid focus on alleviating poverty into the country's long-term development strategy. The acknowledgement of blueprints for Malaysian insufficiency income had raised for attentive actions. Incorporated into the system were a blend of ongoing social assistance and a new drive towards self-sufficiency. Hence, the policy improved more significant capacity building, and further steps to protect the weak have been implemented or the so-called bottom millions of societies.

Up to now, there are remaining vulnerable populations experiencing the poverty line for geographical and societal reasons, although the declining poverty rate. It was necessary to make changes to the poverty line in its early iteration to account for the discrepancy in the mean of household size and expenditures between Peninsular Malaysia's three central regions, Sabah and Sarawak. To eradicate this issue, The Government has maintained its jurisdiction by encouraging income generation, amenities 
provision to uplift the life quality, and execution programs to inculcate positive values in the impoverished (Economic Planning Unit (EPU), 2017). Inspired by Muhammad Yunus's microcredit scheme in Bangladesh, implementing the same program in Malaysia was proposed to reduce poverty (Mohd Nor \& Senthi, 2019; Mukhlisin, Tamanni, Azid, $\&$ Mustafida, 2020). The microfinance initiative aimed to reduce disadvantaged people's reliance on the Government.

Whereas males can be too unenthusiastic to make money in a way that raises their family's financial standing, women are prepared to do so. In addition to being committed to their family, they have an entrepreneurial propensity to look into and enhance. In addition, women are responsible for their debts repayment schedule. A record number of women entrepreneurs have established themselves during the past few years, breaking the previous records (Xheneti, Karki, \& Madden, 2019). Because small businesses have been the primary driver for new job development historically, thus the tremendous increase of women's business is significantly related (Beriso, 2021).

Conversely, Bajpai (2014) claimed that women encountered limitations in experience, ability, experience due to their nature compared to men. Abd Rani and Hashim (2015) further agreed that the contribution factor caused by networking, gender discrimination, and venture into less risky business caused this environment. Nevertheless, many obstacles and restrictions challenged them, and they undeniably significantly contributed to the nation's economy (Fong, Jabor, Zulkifli, \& Hashim, 2019; Shaikh, 2020). Up to this point, the number of women involved in the business is staggering (Abd Rani \& Hashim, 2015).

Consequently, numerous microfinance programs worldwide have disproportionately geared towards women in response to the previous facts and statistics. Essential is the Grameen Bank, which provides financial assistance to disadvantaged women throughout Bangladesh. Following the Grameen Bank's microfinance concept in Bangladesh, many countries have adopted the model. In Malaysia, the Government established Amanah Ikhtiar Malaysia (AIM) on 17 September 1987. The establishment of AIM is to cater to the need sof women's microfinance to assist them in starting up their businesses. Besides AIM, women involved in business can obtain small loans from a variety of sources, including the Government through various institutions such as TEKUN, Majlis Amanah MARA (The Trust of Bumiputra), and Bank Simpanan National (BSN) (Hamid, Mohamed, \& Abdullah, 2019; Othman, 2015).

Microfinance is gaining importance to create jobs, provide income for the poor, 
and alleviate poverty. Many studies of microfinance look at different programs and institutions providing microfinance support (Khan et al., 2020; Mohamed \& Fauziyyah, 2020; Sharma, Guptu, Sharma, \& Sharma, 2021; Siti-Nabiha \& Siti-Nazirah, 2021). These factors would be of paramount importance for understanding the depth and position of microfinance within women entrepreneurs. In contrast, only a handful of studies take a comprehensive look at the roles played by personality, culture, environment, entrepreneurial, microfinance, and their relationship to poverty alleviation, as the research seeks to uncover decisive aspects of socio-economic improvement and poverty alleviation in women-owned small businesses. Therefore, the primary goal of this study is to investigate the factors that influence alleviating poverty. It involves entrepreneurs, particularly women in Kelantan, Terengganu, and Sabah. The study thoroughly examines the determinant factors in alleviating poverty of women entrepreneurs on how they capitalize microfinance in their business undertaking and the other factors that influence eradicating poverty.

\section{LITERATURE REVIEW AND HYPOTHESES DEVELOPMENT}

The literature review section explains the literature on poverty alleviation and continues with the hypothesis in its entirety and the framework as the basis of study development.

\section{Poverty alleviation}

In today's society, poverty alleviation is a significant issue addressed at all levels. It has taken the lead when previous macro-economic development strategies have failed to produce the expected results in eradicating poverty and open the door for adjustments in strategy development aimed primarily at targeted poverty (Liu, Liu, \& Zhou, 2017; Ma'ruf \& Aryani, 2019; Mohamad, Masron, \& Ibrahim, 2021; Sutter, 2019). Every year, due to the expanding diversity of human poverty, a rising percentage of the world's population falls below the poverty line. In contrast to conventional financial institutions, the revolutionary of microfinance was unique in its ability to provide financial assistance to those in need. The concept of doing so removed the vulnerabilities and reduced poverty while promoting productivity, entrepreneurship, and socioeconomic. In a socio-economic context, poverty is a global challenge, and countries are struggling to address the issues 
of poverty (Yang \& Liu, 2021).

Tackling poverty would require narrowing the characteristics of poverty while simultaneously ascertaining to identify poor persons within the population; with abundant definitions and notions accessible in literary writings authored by a diverse range of scholars, poverty shaped into four core ideas: monetary, capability, social exclusion, and participatory (Beck, Hahn, \& Lepenies, 2020; Kwadzo, 2015; Madanipour, Shucksmith, $\&$ Talbot, 2015). Some definitions in this section include setting a financial poverty level and setting out poverty in an all-encompassing manner. In broad, poverty refers to insufficient money or a scarcity of possessions and having minimal competence, confidence, and empowerment (Gamboa, Mingorria, \& Scheidel, 2020; Polas, Raju, Muhibbulah, \& Tabash, 2021). Poverty can result from the household's inability to produce enough income to support themselves. Those in need faced financial access and a lack of other supervision in guiding them (Dalton, Ghosal, \& Mani, 2016), while poverty alleviation enhances the impoverished that focus on their daily lives (Yang, Sherbinin, \& Lu, 2020).

\section{Personality}

Personality is a precursor to the opportunity to pursue behaviour associated with entrepreneurship (Abd Rani \& Hashim, 2015). The acquisition of personal characteristics facilitates the entrepreneurs to carry out the roles effectively. The individual factor may hinder the ability the succeed of entrepreneurs if they lack specific features. Without the necessary demeanours, some are unable to pursue the function of an entrepreneur. The results of previous research shed light on several characteristics of the entrepreneur, in particular, the need for independence, the drive for success, locus of control, the propensity for taking risks, gaining knowledge, and gathering information, and the sense of opportunity are all characteristics of successful people.

The conviction in own abilities is known as self-efficacy. In general, personal selfefficacy substantially impacts overall performance and entrepreneurial inclination (Hoque, Awang, Muda, \& Salleh, 2018). Self-efficacy is a distinctive entrepreneur personality trait (Kazeem \& Asimiran, 2016). When we look at the connection between internal locus of control and entrepreneurial spirit, it appears that a higher internal locus of control is related to a greater sense of entrepreneurship than a lower internal locus of control, which seems to lead to a smaller entrepreneurial spirit. (Asante \& Affum-Osei, 
2019).

It has been proven in numerous studies that within the entrepreneurs, entrepreneurs should inspire the management ability, business performance competitiveness, and entrepreneurial experience should be encouraged to boost the determination (Ong, Habidin, Salleh, \& Fuzi, 2016). The entrepreneur is energized for their business survival (Bajpai, 2014) and expanding to grow in the future (Asante \& Affum-Osei, 2019). In the field of entrepreneurship, a proclivity for taking risks is a hugely important feature to consider. It describes persons who are susceptible to taking risks when confronted with situations that may be ambiguous or risky. In the field of entrepreneurship, a proclivity for taking risks is a hugely important feature to consider. It describes persons who are made liable for taking risks during confronting disputes (Linton, 2019).

Alene (2020) observed women's experiences of developing countries working in self-organized groups such as micro-enterprises. They recorded the positive outcomes, including personal, interpersonal, community and organizational, and economic changes. In addition, they claim they have gained social and emotional support, group and organizing skills, and rights awareness and protection throughout their involvement and attachment with the group. It means that hypotheses are proposed in such a way.

\section{H1: Personality has a positive relationship with poverty alleviation.}

\section{Cultural}

There are many mechanisms for entrepreneurs to succeed, and one of them is the development of cultural attitudes, which is positively associated with the motivating drive for business growth (Mohd Yusof, Jabar, Murad, \& Ortega, 2017). Culture is a beneficial catalyst for business start-ups. Diversities of cultures include languages, values, ethnic groups, religions, and beliefs. Diversity in the cultural environment may impact behavioural characteristics, particularly women entrepreneurs (Anggadwita, Luturlean, Ramadani, \& Ratten, 2017).

To a certain, the concept of cultural differences has presented as a significant determining factor in the availability of entrepreneurship in various regions and (Apetrei, Kureshi, \& Horodnic, 2015). During one of the studies on women in Spain, Noguera, Alvarez, and Urbano (2013) revealed that when it comes to being a successful women entrepreneur, among the most significant obstacles were "fear of failure" and "perceived 
capabilities". In addition, as agreed by Anggadwita et al. (2017), women in Indonesia face hurdles in entrepreneurship that include cultural barriers. Entrepreneurial activities are cultivated through frequent educational programs and support policies that promote values. Furthermore, according to the literature on entrepreneurship, socio-cultural elements such as family, fearfulness, capabilities are most critical in driving entrepreneurial persistence (Anggadwita et al., 2017; Mohd Yusof et al., 2017).

There is a potentially strong impact of the socio-cultural environment on the operations of microfinance organizations and the relative merits of different approaches (Haque, Siswar, Ghazali, Said, \& Bhuiyan, 2021). Growth in the number of borrowers, for example, enhances the chances that microfinance institutions will transition to and operate in a full-fledged service market. Finally, Zakat should be practised within the entrepreneurship literature's growth and implemented by the societies as part of poverty minimization efforts (Hoque, Khan, \& Mohammad, 2015). Therefore, it can hypothesize that:

\section{H2: Cultural has a positive relationship with poverty alleviation.}

\section{Environment}

Women's entrepreneurial activity appears to be more successful when aspects of the business environment need to consider. Local business environments, market access, the country's labour force's stability, raw material accessibility, and the excellent creation product process are all critical components of the work environment. The efficiency of production and marketing are essential factors in determining the success of an enterprise. However, women, especially entrepreneurs, have difficulties maintaining both productivity and efficiency as marketers due to their lacking ability in both management and technology (Shah \& Saurabh, 2015).

Several obstacles confront businesses due to events that are beyond their control, such as the business environment. However, as these characteristics are only necessary for entrepreneurship, business variables such as training, a risk-taking attitude that is acceptable, drive, excitement, and prior business experience are more important in this field. The environment may make it more difficult for women entrepreneurs to take advantage of entrepreneurial opportunities, even if they possess the requisite personal entrepreneurial characteristics (Mozumdar, Hagelaar, van der Velde, \& Omta, 2020; Tadesse, 2020). 
In addition, the ability to learn is a fundamental component of any thriving business culture. It requires an understanding of the product's breadth and market trends. Expert and management skills are examples of job abilities that develop through appropriate training and experience (Kamberidou, 2020). Among other things, genderbased discrimination in the workplace and environmental constraints, particularly in developing countries, are obstacles to women starting their businesses. Furthermore, it is vital to strengthen the poor's ability to break away from poverty as part of a poverty alleviation plan. It can accomplish through health, education, and vocational training facilities (Hoque et al., 2015). Thus, the hypothesis is postulated as follows.

\section{H3: Environment has a positive relationship with poverty alleviation.}

\section{Microfinance}

As for microfinance's economic and social impact, and the results have been varied. Many studies have been undertaken, particularly of the social and economic aspects in managing microcredit activity. The development of the studies is varied. For example, Al-shami, Razali, Majid, Rozelan, and Rashid (2016), studied the impact on microcredit access and identified the determinants factor contributed to the microfinance firm strategy. Based on data from 16 states, the findings significantly mentioned that its crucial impact is to analyze the microcredit access, which helps reduce the lower-income group headcount and develop the family's economic well-being and narrow the income inequality gap. Selvaraj, Karim, Abdul-Rahman, and Chamhuri (2018) examined the effect of microfinance on women entrepreneurs' empowerment. The findings show that microfinance empowerment resulted in significant gains in the business's revenue and the enhancement of individuals in general and women in particular. People who use microfinance reported that these were some of the changes they saw, along with increased public regard, acceptability, higher self-esteem, community involvement, and monetary contributions to socially beneficial projects. It also provided the women entrepreneur with the capability in controlling and decide on their resources.

Microfinance has received widespread acceptance as a viable tool for global poverty alleviation and well-being development (Haque et al., 2021; Mohd Nor \& Kumar, 2021). This method considers being beneficial to the economy at the local stage. The rapid expansion of activities for microfinance has the potential to contribute to the realization of a wide range of development goals, including the fulfilment of self- 
employment aspirations, the establishment of new business, and the distribution of income (Al-shami, Majid, Rashid, \& Hamid, 2014). Aside from assisting businesses with capital investments, microfinance can also assist households in improving their economic well-being. Microfinance also includes a holistic approach to empowering the underprivileged (Shaheen, Hussain, \& Mujtaba, 2018). It empowers them to make their own decisions, improves the quality of their lives, and enhances their dignity (Mecha, 2017).

Mahmood, Hussain, and Matlay (2014) investigated alleviating poverty, entrepreneurship, and microfinance with involved three phases. In the first phase, women cannot see clearly because of poverty clouds that veil their vision. This is where women in the community learned about a microfinance program and were exposed to entrepreneurial opportunities. As a result of empowerment and enterprise, the following phase is marked by an improvement that provides access to further money and entrepreneurial characteristics. Entrepreneurs expanded the business using microfinance loans, whether a new venture or an existing family enterprise. The third phase focuses on microfinance organizations that provide financial assistance, training, and product knowledge in establishing business networks and peer mentorship programs.

The findings of their study revealed that women in the sample had experienced a considerable improvement in the overall quality of their lives due to gaining access to microfinance. Thirty per cent of the women shifted from phase 2 to phase 3 because of more business options. Product knowled ge, training, business networks, peer mentorship, and budgeting are just a few examples. Twenty per cent of the entrepreneurs were able to advance into the next phase of success, which is phase 3 , during which they experienced significant poverty alleviation and increased opportunistic opportunities. Agbola, Acupan, and Mahmood (2017) employ a mixed-method approach that uses 211 respondents from the Philippines' Northeastern Mindanao on the impact of microfinance on poverty reduction and general happiness. Based on the findings, microfinance has been shown to help alleviate poverty while also improving the general well-being of the poor.

\section{H4: Microfinance has a positive relationship with poverty alleviation.}

\section{Entrepreneurial}

Entrepreneurial elements that contributed to the success of entrepreneurs have been previously found in previous research. Ismail, Rahim, Kamal, Mat, and Husin 
(2015) indicate that an entrepreneur should have a strong desire to attain success. Other distinguishing characteristic includes an inner locus of control (Tentama \& Dahlan, 2020), self-confidence, independence (Khan, Salamzadeh, Shah, \& Hussain, 2021) and innovativeness, as well as effective decision-making and communication abilities (Kirkley, 2016). Additionally, an entrepreneur must be capable of dealing effectively with any challenges that may arise while developing a new enterprise (Kusa, Duda, \& Suder, 2021). Risk-taking is a significant ingredient to establish a personality for entrepreneurs. It would assist the entrepreneurs in managing the day-to-day business operations (Kerr, Kerr, \& Xu, 2018). Additionally, there are certain traits of successful entrepreneurs, such as high self-efficacy, opportunity recognition, perseverance, and social skills (Wasdani \& Mathew, 2014).

Innovativeness and excellent interpersonal, mental, and technical ability are essential attributes for achieving entrepreneurial success (Shahzad, Khan, Saleem, \& Rashid, 2021). Furthermore, having a goal-oriented mindset and being realistic, motivated, more flexible, and self-assured are distinguishing characteristics that benefit business owners. The knowledge gained from various points, such as grooming or individual experience, whether through official or informal schooling, is another crucial factor in developing successful entrepreneurs (Jimenez, Palmero-Camara, GonzalezSantos, Gonzalez-Bernal, \& Jimenez-Eguizabal, 2015). Understanding one's surroundings can assist an entrepreneur in becoming imaginative and sparking new ideas, allowing entrepreneurs to seize opportunities that arise in their environment. (Kraus, McDowell, Ribeiro-Soriano, \& Rodriguez-Garcia, 2021).

Lack of sufficient numbers of promising entrepreneurs contributes to poverty ( $\mathrm{Si}$, Ahlstrom, Wei, \& Cullen, 2019). Sadri (2010) explains that entrepreneurship is a cause and outcome of economic success, technological improvement, conceptual innovation, and a network of interknitted, intertwined, and interwoven relationships. In contrast, resource endowments, population size, economic and social policies, and the types of economic activities carried out are factors that influence poverty levels. (Ota, 2016). Thus, based on previous studies and above arguments, the following is posited:

\section{H5: Entrepreneurial has a positive relationship with poverty alleviation.}




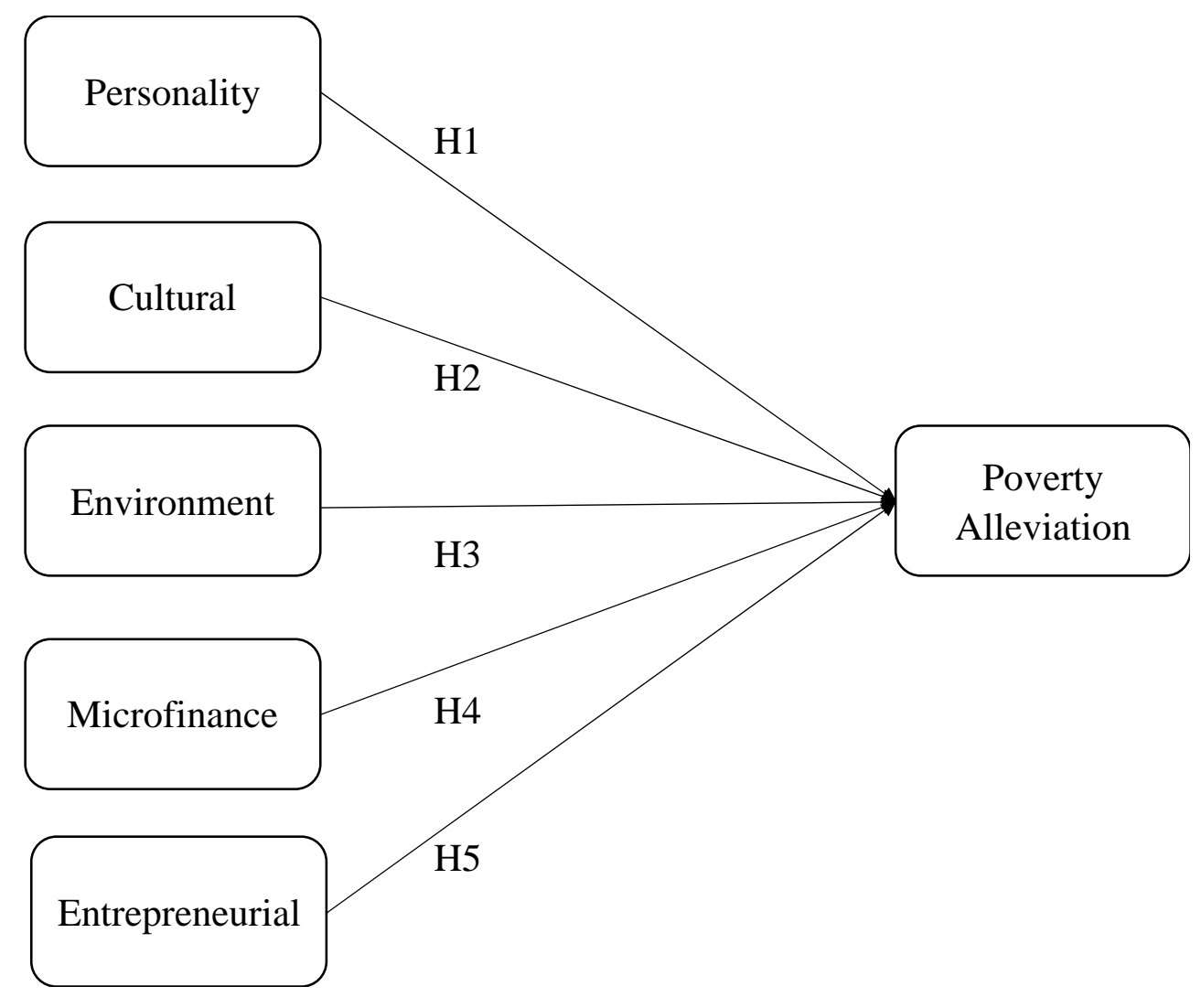

Figure 1: Research Framework

\section{METHODOLOGY}

A quantitative technique was used to estimate the prevalence of women's entrepreneurship in alleviating poverty. In this study, purposive sampling was used, which means that samples were taken from a specific group of people who were likely to have the information needed, either because they were the only ones who had it or because they met specific criteria established by the researchers (Sekaran, 2003). A selfadministered questionnaire was used as the survey tool. It was designed using a multiitem scale to enable the measurement of all relevant constructs. Questions were structured into three sections. Section A assessed respondent's knowledge of the variables that contribute to poverty alleviation. Section B assesses the extent to which respondents' poverty has been alleviated. In these sections, a Likert scale is used, with responses ranging from "Strongly disagree" (with represent of 1) to "Strongly agree" (with a mean of 5). Women entrepreneurs' profiles were compiled, including information on their business possession, skill, level of education, business premises, race, and age stated in 
section C. All items except in Section C were measured using a five-point Likert scale. The source of measurement items is as shown in Table 1.

Table 1. Source of Measurement Items

\begin{tabular}{lcl}
\hline Construct & No. of Item & Source \\
\hline Personality & 5 & $\begin{array}{l}\text { Gurol and Atsan (2006), Arasteh, Enayati, } \\
\text { Zameni, and Khademloo (2012) } \\
\text { Krueger, Linan, and Nabi (2013), Konrad } \\
(2013)\end{array}$ \\
Environment & 5 & $\begin{array}{l}\text { Sambharya and Mustteen (2014), Bhat and } \\
\text { Khan (2014), Mohamad, Ramayah, } \\
\text { Puspowarsito, Natalisa, and Saerang } \\
\text { (2011) }\end{array}$ \\
Kacrofinance & 8 & $\begin{array}{l}\text { Kanayo, Jumare, and Nancy (2013), } \\
\text { Dorado (2013), Samson, Olubunmi, and } \\
\text { Olusegub (2013) } \\
\text { Makhbul and Hasun (2011), Yang (2013), } \\
\text { Mitchelmore and Rowley (2010), Sanchez } \\
\text { (2013), Boyles (2012) } \\
\text { Hussain, Bhuiyan, and Bakar (2014), } \\
\text { Janjua and Kamal (2014) }\end{array}$ \\
\hline Poverty alleviation & 8 & \\
\hline
\end{tabular}

The small enterprise had to meet the requirement that companies with fewer than 75 full-time employees and more than one year of experience are eligible to participate in this research to consider prospective respondents. It is required that the respondent is the company owner or management and a participant in a microfinance program. Our research takes place in three Malaysian states, namely Terengganu, Kelantan, and Sabah. The rationale for selecting the states in this study is that conditions are among the poorest states and highest poverty levels in Malaysia, with which indigenous people make up most of the population. In conformity with Lim (2020), based on data from 2019, Sabah has the highest poverty rate at 19.5 per cent, then Kelantan (with 12.4 per cent of the total) and Terengganu at the rate of 6.1 per cent. The World Bank has revealed data in 2020, and Sabah remains the most impoverished state in Malaysia (World Bank Group, 2020).

The survey was conducted over two months. 360 self-administered questionnaires were distributed to the identified respondents. With approximately two months of $\mathrm{d}$ ata collected, there were 300 questionnaires accepted in this study. The remaining surveys in this study were not accepted since the respondents did not respond to some questions. The collected data were coded, then entered into the IBMSPSS version 23. The normality test was performed through the web power, which can assess via online to measure Multivariate Skewness and Kurtosis as proposed by Hair, Matthews, Matthews, and 
Sarstedt (2017). The measurement and structural model were examined using the Partial Least Square-Structural Equation Modelling (PLS-SEM) version 3.2.8. The purpose of the measurement model is to determine the validity of the relationships between items and the constructs in the study framework. Both convergent validity and discriminant validity must be met in the measurement model for it to be considered valid. After evaluating the measurement model, the path analysis was carried out to investigate the structural model relationships among the constructs.

\section{RESULTS}

The demographic characteristics of the respondents are shown in Table 2. According to the information we gathered, most respondents were between the ages of 40 and 49, accounting for 33 per cent of the total number of respondents. According to the data we obtained, 160 persons have attended primary school, accounting for 53 per cent of those who fall into this category. Respondents with non-formal training have the highest percentage of participation in the business, which holds 73 per cent of all respondents in this category. A total of 158 respondents who took part in the research were on running businesses at their shops. It was represented 53 per cent of the total respondents. Respondents who held sole proprietorships accounted for the most significant proportion of respondents in the category of possession of the business, accounting for 266 persons, which is equivalent to 89 per cent of all respondents. 
Table 2. Demographic Characteristics

\begin{tabular}{lcc}
\hline Demographic Variable & Frequency & $\%$ \\
\hline Age & 48 & 16 \\
20-29 years old & 61 & 20 \\
30-39 years old & 97 & 33 \\
40-49 years old & 94 & 31 \\
Above 50 years old & & \\
Education & 37 & 21 \\
Non-formal education & 64 & 53 \\
Primary school & 160 & 10 \\
Secondary school & 27 & 3 \\
Diploma & 9 & \\
Degree & 3 & 73 \\
Postgraduate & & 10 \\
Skill & 218 & 13 \\
Non-formal training & 31 & 4 \\
Vocational training & 40 & \\
Part time training & 11 & 45 \\
Training at College & & 53 \\
Type of business premises & 135 & 2 \\
Stall & 158 & \\
Shop & 7 & 89 \\
Kiosk & & 3 \\
Possession of business & 266 & 3 \\
Sole proprietorship & 24 & \\
Partnership & 10 & \\
Branches & &
\end{tabular}

A variance-based software package called PLS-SEM is suited for the research model in the study that is concerned with the prediction between variables. The regression analysis is still used in Smart PLS, although it is based on structural equation modelling. To determine whether the will be normal or not, we have performed the normality test. Hair, Matthews, et al. (2017) proposed the web power, which can assess online to measure Multivariate Skewness and Kurtosis ${ }^{\mathrm{C}}$. The result for Mardia's Multivariate Skewness was $\beta=5.522$ and $p<0.01$. At the same time, the result for Mardia's Multivariate Kurtosis was found to be $\beta=61.976$ and $p<0.01$ ). The data normality procedure highlighted that if the skewness is \pm 1 and Kurtosis is \pm 7 , the data is considered normal.

In this study, Smart PLS software was employed because the data was slightly out of normal. In the following step, we examined the Common Method Variance (CMV) to resolve the issue arising during the study since the data collected was not from multiple sources. (Podsakoff, MacKenzie, Lee, \& Podsakoff, 2003). Thus, the Harman single factor test (HSFT) was used to perform the analysis. If the first factor explained more than 50 per cent of the study's variance, the CMV faces a severe issue for the study

C Multivariate Skewness and Kurtosis output in this study can be found at the following link https://webpower.psychstat.org/models/kurtosis/results.php?url=5c640b552841f7a3d6ed9fe71a59c588. 
(Pod sakoff et al., 2003). However, it confirms that the analysis's first factor was 43.5 per cent, which explained total variance (Ringle, Wende, \& Becker, 2015) to test the research hypothesis. Using this method, we need to analyze using two steps of analysis, which consist of i) the measurement model and ii) the structural model (Anderson \& Gerbing, 1988; Hair, Hult, Ringle, \& Sarstedt, 2014).

\section{Measurement Model}

The measurement model establishes the framework on item-construct relationship. It requires two validities in the measuring model: convergent validity and discriminant validity. Factor loading, average variance explained (AVE), and composite reliability $(\mathrm{CR})$ are used to assess convergent validity. It needs to meet the requirement of the factor loading of $\geq 0.5, \mathrm{AVE}$ of $\geq 0.5$, and $\mathrm{CR}$ of $\geq 0.7$. Table 3 presents the value of factorloading, AVE, and CR, which are meet more than the minimum threshold values established by Hair et al. (2014). The range of factor loading is between $0.616-0.874$. In contrast, the AVE shows that ranging between $0.538-0.655$ and the result of CR in between $0.853-0.944$. As a result, it confirms that convergent validity is accepted in the study.

\begin{tabular}{|c|c|c|c|c|c|}
\hline Construct & Item & Loading & CR & AVE & $\begin{array}{c}\text { Cronbach's } \\
\text { alpha }\end{array}$ \\
\hline \multirow[t]{5}{*}{ Personality } & PER1 & 0.849 & 0.890 & 0.621 & 0.842 \\
\hline & PER2 & 0.812 & & & \\
\hline & PER3 & 0.800 & & & \\
\hline & PER4 & 0.828 & & & \\
\hline & PER5 & 0.633 & & & \\
\hline \multirow[t]{5}{*}{ Cultural } & CUL1 & 0.726 & 0.853 & 0.538 & 0.782 \\
\hline & CUL2 & 0.654 & & & \\
\hline & CUL3 & 0.772 & & & \\
\hline & CUL4 & 0.760 & & & \\
\hline & CUL5 & 0.749 & & & \\
\hline \multirow[t]{8}{*}{ Environment } & ENV1 & 0.751 & 0.910 & 0.561 & 0.886 \\
\hline & ENV2 & 0.735 & & & \\
\hline & ENV3 & 0.780 & & & \\
\hline & ENV4 & 0.616 & & & \\
\hline & ENV5 & 0.759 & & & \\
\hline & ENV6 & 0.757 & & & \\
\hline & ENV7 & 0.771 & & & \\
\hline & ENV8 & 0.807 & & & \\
\hline \multirow[t]{6}{*}{ Microfinance } & MIC1 & 0.791 & 0.928 & 0.617 & 0.911 \\
\hline & MIC2 & 0.834 & & & \\
\hline & MIC3 & 0.851 & & & \\
\hline & MIC4 & 0.765 & & & \\
\hline & MIC5 & 0.740 & & & \\
\hline & MIC6 & 0.747 & & & \\
\hline
\end{tabular}




\begin{tabular}{|c|c|c|c|c|c|}
\hline \multirow{5}{*}{ Entrepreneurial } & MIC7 & 0.759 & \multirow{4}{*}{0.944} & \multirow{4}{*}{0.606} & \multirow{4}{*}{0.933} \\
\hline & MIC8 & 0.792 & & & \\
\hline & ENT1 & 0.780 & & & \\
\hline & ENT2 & 0.781 & & & \\
\hline & ENT3 & 0.813 & \multirow{17}{*}{0.938} & \multirow{17}{*}{0.655} & \multirow{17}{*}{0.922} \\
\hline \multirow{16}{*}{$\begin{array}{l}\text { Poverty } \\
\text { Alleviation }\end{array}$} & ENT4 & 0.813 & & & \\
\hline & ENT5 & 0.797 & & & \\
\hline & ENT6 & 0.754 & & & \\
\hline & ENT7 & 0.709 & & & \\
\hline & ENT8 & 0.791 & & & \\
\hline & ENT9 & 0.809 & & & \\
\hline & ENT10 & 0.782 & & & \\
\hline & ENT11 & 0.730 & & & \\
\hline & POV1 & 0.833 & & & \\
\hline & POV2 & 0.834 & & & \\
\hline & POV3 & 0.874 & & & \\
\hline & POV4 & 0.849 & & & \\
\hline & POV5 & 0.812 & & & \\
\hline & POV6 & 0.790 & & & \\
\hline & POV7 & 0.797 & & & \\
\hline & POV8 & 0.668 & & & \\
\hline
\end{tabular}

Next step, the discriminant validity of a construct is determined. The construct is distinct from the other construct and measures how many indicators represent a single construct (Gholami, Sulaiman, Ramayah, \& Molla, 2013). Due to criticism of Fornell \& Larcker's (1981) criterion, the study will report the discriminant validity using the Heterotrait-Monotrait ratio of correlation (HTMT) as proposed by Henseler, Ringle, and Sarstedt (2015). This indicates a catastrophic problem with discriminant validity if the HTMT value is more significant than 0.85 (Kline, 2015). Table 4 illustrates that the study's discriminant validity was established because all HTMT were below the most conservative value (Kline, 2015).

Table 4. Discriminant Validity: HTMT

\begin{tabular}{lllllll}
\hline Construct & PER & CUL & ENV & MIC & ENT & POV \\
\hline PER & & & & & & \\
CUL & 0.751 & & & & & \\
ENV & 0.733 & 0.765 & & & & \\
MIC & 0.662 & 0.718 & 0.768 & & & \\
ENT & 0.773 & 0.696 & 0.753 & 0.760 & & \\
POV & 0.725 & 0.622 & 0.700 & 0.748 & 0.750 & \\
\hline
\end{tabular}




\section{Structural Model}

The bootstrapping with a re-sampling of 500 was used for the hypotheses testing. This procedure was recommended by (Hair, Hollingsworth, \& Randolph, 2017). To decide on the acceptance of the hypothesis, the value of i) t-value, ii) p-value, and iii) confidence interval bias-corrected need to meet the criteria. According to the analysis results, only three hypotheses were supported out of the five produced. The findings indicate that personality has a significant relationship with poverty alleviation $(\beta=0.226$, $\mathrm{t}=4.034: \mathrm{LL}=0.140, \mathrm{UL}=0.315, \mathrm{P}<0.01)$. As a result, $\mathrm{H} 1$ is supported. Microfinance, on the other hand, has a significant relationship with poverty alleviation $(\beta=0.322, \mathrm{t}=$ 4.511: $\mathrm{LL}=0.213, \mathrm{UL}=0.447, \mathrm{P}<0.01)$. Thus, $\mathrm{H} 4$ is supported. Entrepreneurial has also significant relationship with poverty alleviation $(\beta=0.255, \mathrm{t}=3.337$ : $\mathrm{LL}=0.121$, $\mathrm{UL}=0.363, \mathrm{P}<0.01$ ), which resulted $\mathrm{H} 5$ is supported. In addition, other result found that cultural were $\beta(-0.028)$, t (0.441), LL (- 0.148), UL (0.063), and P (>0.05). While environmental were $\beta$ (0.115), t (1.563), LL (-0.017), UL (0.226), and P (>0.05). Thus, the result shows that both $\mathrm{H} 2$ and $\mathrm{H} 3$ were unsupported.

Table 5. Hypothesis Testing

\begin{tabular}{clccccccc}
\hline Hypothesis & Relationship & Beta & Se & $\begin{array}{c}\text { T- } \\
\text { Value }\end{array}$ & P-Value & LL & UL & Decision \\
\hline H1 & PER->POV & 0.226 & 0.056 & 4.034 & 0.001 & 0.140 & 0.315 & Supported \\
H2 & CUL->POV & -0.028 & 0.064 & 0.441 & 0.330 & -0.148 & 0.063 & Unsupported \\
H3 & ENV->POV & 0.115 & 0.073 & 1.563 & 0.059 & -0.017 & 0.226 & Unsupported \\
H4 & MIC->POV & 0.322 & 0.071 & 4.511 & 0.001 & 0.213 & 0.447 & Supported \\
H5 & ENT->POV & 0.255 & 0.076 & 3.337 & 0.001 & 0.121 & 0.363 & Supported \\
\hline
\end{tabular}

Table 6 presents the result of the coefficient of determination $\left(\mathrm{R}^{2}\right)$, the effect size $\left(f^{2}\right)$, and the predictive relevance $\left(\mathrm{Q}^{2}\right)$ of exogenous variables are assessed. $\mathrm{R}^{2}$ of 0.607 highlighted that Personality, cultural, environmental, microfinance, and entrepreneurial explain 60.7 per cent of the overall variance of poverty alleviation. The decision followed the guidelines of Hair et al. (2014), whereby $\mathrm{R}^{2}$ values of 0.75 (substantial), 0.5 (moderate), and 0.25 (weak). Therefore, with the $\mathrm{R}^{2}$ of 60.7 per cent, it can explain 60.7 per cent of the overall variance in poverty alleviation. According to Hair et al. (2014), when employing the blindfolding process to test predictive relevance, a $\mathrm{Q}^{2}$ greater than 0 indicates the model has predictive relevance. Specifically, the study discovered that the 
$\mathrm{Q}^{2}$ is 0.391, which is greater than 0, as previously stated by Hair et al. (2014); as a result, the study may claim that the structural model for that construct has a predictive accuracy.

Finally, $f^{2}$ was used to explain the endogenous variable, determining which variable is essential than the other. According to Cohen (1988), the effect sizes of 0.35, 0.15 , and 0.02 are considered large, medium, and small effect sizes, respectively. As a result, the variables of Personality (0.058), microfinance (0.105), and entrepreneur (0.06) have a negligible effect size on poverty alleviation.

Table 6. Coefficient of determination, effect size, and predictive relevance

\begin{tabular}{lllll}
\hline & $\boldsymbol{f}^{2}$ & & $\mathbf{R}^{2}$ & $\mathbf{Q}^{2}$ \\
\hline PER & 0.058 & Small & 0.607 & 0.391 \\
MIC & 0.105 & Small & & \\
ENT & 0.060 & Small & & \\
\hline
\end{tabular}

\section{DISCUSSION AND CONCLUSION}

The result showed the key predictors are personality, microfinance and entrepreneurial as they significantly influenced poverty alleviation among women entrepreneurs. Meanwhile, cultural and environment have no influence and thus is not considered as the predictor. It has been understood from the findings that the personality factorhas a significant positive relationship with poverty alleviation. This result is aligned with previous literature, which mentioned that personality had been suggested as a predictor of entrepreneurial alertness to business prospects (Biswas \& Verma, 2021). Agustina and Pradesa (2020) also claimed that a tendency for risk-taking is a very significant dimension of an entrepreneur when faced with uncertain situations.

Next, the finding provides important evidence that microfinance also predicts poverty alleviation. Previously, the study of Ussif (2020) and Chomen (2021) demonstrated that microfinance initiatives assisted in attaining considerable improvements in business earnings, access to life-enhancing services, and the empowerment of people, particularly women. As a result of their increased public regard, acceptance, and self-esteem, they have become more involved in community activities and have made more significant monetary contributions to charitable organizations. Furthermore, microfinance has gained widespread acceptance as an efficient tool for poverty alleviation and well-being development. (Al-shami, Razali, \& Rashid, 2017; Bongomin, Woldie, \& Wakibi, 2020). 
Furthermore, this study also found a significant relationship between entrepreneurship and poverty alleviation. The entrepreneurship is found to have a strong significant and positive relationship with poverty alleviation. An entrepreneur needs certain qualities to make them a real entrepreneur, like an inner locus of control (Tentama \& Dahlan, 2020), self-confidence, independence (Khan et al., 2021) and innovativeness as well as good communication and decision-making skills (Kirkley, 2016). An entrepreneur must also be able to face any possibilities effectively during the establishment of a new venture. This implies that they are a risk taker (Kerr, Kerr, \& Xu, 2017) and hence, it is one of the most important qualities of an entrepreneur.

Surprisingly, the environment was not a significant predictor of poverty alleviation. This is unparallel with Shastri and Sinha (2010). They asserted that, despite the possession of necessary personal entrepreneurial characteristics such as instruction, a risk-taking attitude, motivation, energy, and working experience, the environment might prevent women entrepreneurs from taking advantage of available business opportunities. The insignificant could be attributed to those women entrepreneurs' encountered obstacles in handling their business, which is beyond their control. This is supported by the study by Mozumdar et al. (2020) highlighted that the environment may make it more difficult for women entrepreneurs. In addition, Tadesse (2020) found that women confront gender bias in the workplace, and they have less bargaining power and access to economic resources than males. They will be unable to start and grow their businesses as a result of this.

The study also found that cultural was not supported. Like the fourth relationship, the result showed that cultural was no significant relationship with poverty alleviation. This is supported by Begley and Tan (2001) who argued that cultures with various cultural values go through several stages of entrepreneurial activity. Therefore, this result indicated that cultural does not significantly influence poverty alleviation in Kelantan, Terengganu and Sabah. Aggarwal and Rahul (2017) agreed on women faces hurdle in entrepreneurship, which includes cultural barriers.

In conclusion, it was demonstrated that five variables were discovered: personality, culture, environment, microfinance, and entrepreneurial on women entrepreneurship in the direction of poverty alleviation. Microfinance is said to have the most significant impact on women's entrepreneurship and minimize the rate of poverty. The findings are pertinent to women entrepreneurs as they demonstrate that microfinance was the primary element in business operation. According to Hatta and Ali (2013), in 
positive association, the microfinance element creates the potential for entrepreneurial activity to expand. Besides facilitating the business operation and investment, microfinance guided the financial well-being and improvement of households economics.

Insufficient debt recovery and favourable financial assistance impact poverty reduction significantly contributed to this program (Mokhtar \& Ashhari, 2015). Equally important, the microfinance program is growing important as the focal basis in providing new employment opportunities and income possibilities to help those in need and improve the socioeconomic position of the poor while eliminating poverty. Since microfinance is indispensable in the fight against poverty as it gives access to a financial pathway, it condones to be grateful.

\section{RESEARCH IMPLICATIONS}

On a broad level, this study contributes to the body of knowledge on poverty alleviation, with a particular emphasis on the Malaysian entrepreneurship environment. Because the present literature is still in desperate need of Malaysian literature, the findings of this study are regarded as valuable contributions to the body of knowledge in this field. This study presents empirical evidence of the relationship between personality, cultural, the environment, microfinance, and entrepreneurship with poverty alleviation among woman entrepreneurs, specifically in the context of microfinance. In general, this study gives empirical findings of the relationships that were investigated. With the exception of two relationships, all of the results obtained are supported by the literature. The practical consequences of this study are highly relevant to policymakers as well as to female business owners. Specifically, the findings of this study are intended to provide insight into respondents' perceptions of current policies and the effects of the components indicated above on poverty reduction. They could use this information to improvise the aspects that influence poverty reduction. However, this study may help women entrepreneurs understand the value of personality, cultural, environment, microfinance, and entrepreneurship in assisting them to thrive in business and help eliminate poverty from their lives as a result of reading it. 


\section{LIMITATION AND FUTURE DIRECTION}

Despite the fact that it produced favourable results, this study has some limitations that should be addressed in future research. For starters, this study only focuses on five independent variables that have a significant impact on poverty reduction. Several other determinants can be considered as contributions to this research as well. Researchers could examine the correlations between additional independent variables or causes and poverty alleviation in future work to learn more about the phenomenon. Aside from the significant variables, the items for each variable could be added for the goal of knowledge extension to supplement the main variables. Additionally, it could serve as a model for policymakers and microfinance institutions to improve their regulatory and service practises, thereby contributing to poverty alleviation. Second, the scope of this study was limited to three specific states. To better understand the patterns of woman entrepreneurs dealing with their enterprises to alleviate or eliminate poverty in general, the scope of this study should be increased to include the entire peninsula of Malaysia in future research. The results will be more representative of the effectiveness of microfinance in our country as a result of this growth. As a result, the outcomes will be more valued, and they will make a significant contribution to the body of existing knowledge.

\section{REFERENCES}

Abd Rani, S. H., \& Hashim, N. (2015). Factor that influence women entrepreneurial success in Malaysia: A conceptual framework. Paper presented at the Conference on Business Management Research II (CBMR II), Universiti Utara Malaysia.

Agbola, F. W., Acupan, A., \& Mahmood, A. (2017). Does microfinance reduce poverty? new evidence from Northeastern Mindanao, the Philippines. Journal of Rural Studies, 50, 159-171. doi:10.1016/j.jrurstud.2016.11.005

Aggarwal, A., \& Rahul, M. (2017). Impact of perceived usability and perceived information quality on Indian consumer purchase intentions in online shopping: implication of TAM and S-O-R theory. International Journal Technology Transfer and Commercialisation, 15(2), 160-183. doi:10.1108/JEEE-03-2016-0011

Agustina, I., \& Pradesa, H. A. (2020). Gender differences in risk taking among entrepreneurs : case on small medium enterprise in Malang. Warmadewa Management and Business Journal, 2(2). doi:10.22225/wmbj.2.2.2020.63-72

Al-shami, S. S. A., Majid, I., Rashid, N., \& Hamid, M. S. R. A. (2014). Conceptual framework: the role of microfinance on the wellbeing of poor people cases studies 
from Malaysia and Yemen. Asian Social Science, 10(1), 230-242. doi:10.5539/ass.v10n1p230

Al-shami, S. S. A., Razali, R. M., Majid, I., Rozelan, A., \& Rashid, N. (2016). The effect of microfinance in women's empowerment: evidence from Malaysia. Asian Journal of Women's Studies, 22(3), 318-337. doi:10.1080/12259276.2016.1205378

Al-shami, S. S. A., Razali, R. M., \& Rashid, N. (2017). The effect of microcredit on women empowerment in welfare and decisions making in Malaysia. Social Indicators Research, 137, 1073-1090. doi:10.1007/s11205-017-1632-2

Alene, E. T. (2020). Determinants that influence the performance of women entrepreneurs in micro and small enterprises in Ethiopia. Journal of Innovation and Entrepreneurship, 9(24), 1-20. doi:10.1186/s13731-020-00132-6

Anderson, J. C., \& Gerbing, D. W. (1988). Structural equation modelling in practice: a review and recommended two-step approach. Psychological Bulletin, 103(3), 411423.

Anggadwita, G., Luturlean, B. S., Ramadani, V., \& Ratten, V. (2017). Socio-cultural environments and emerging economy entrepreneurship. Journal of Entrepreneurship in Emerging Economies, 9(1), 85-96. doi:10.1108/JEEE-032016-0011

Apetrei, A., Kureshi, N. I., \& Horodnic, I. A. (2015). When culture shapes international business. Journal of Business Research, 68(7), 1519-1521. doi:10.1016/j.jbusres.2015.01.044

Arasteh, H., Enayati, T., Zameni, F., \& Khademloo, A. (2012). Entrepreneurial personality characteristics of University students: A case study. Procedia - Social and Behavioral Sciences, 46, 5736-5740. doi:10.1016/j.sbspro.2012.06.507

Asante, E. A., \& Affum-Osei, E. (2019). Entrepreneurship as a career choice: The impact of locus of control on aspiring entrepreneurs' opportunity recognition. Journal of Business Research, 98, 227-235. doi:10.1016/j.jbusres.2019.02.006

Bajpai, G. C. (2014). African Women Entrepreneur- Problems, Challenges and Future Opportunities. International Journal of Managerial Studies and Research, 2(5), 17 22.

Beck, V., Hahn, H., \& Lepenies, R. (2020). Interdisciplinary Perspectives on Poverty Measurement, Epistemic Injustices and Social Activism. In V. Beck, H. Hahn, \& R. Lepenies (Eds.), Dimensions of Poverty. Philosopy and Poverty (Vol. 2). doi:10.1007/978-3-030-31711-9_1

Begley, T. M., \& Tan, W.-L. (2001). The socio-cultural environment for entrepreneurship: a comparison between East Asian and Anglo-Saxon Countries. Journal of International Business Studies, 32, 537-553. doi:10.1057/palgrave.jibs.8490983 
Beriso, B. S. (2021). Determinants of economic achievement for women entrepreneurs in Ethiopia. Journal of Innovation and Entrepreneurship, 10(5), 1-14. doi:10.1186/s13731-020-00141-5

Bhat, S., \& Khan, R. (2014). Entrepreneurship and institutional environment: perspectives from the review of literature European Journal of Business and Management, 6(1), 84-91.

Biswas, A., \& Verma, R. K. (2021). Attitude and alertness in personality traits: a pathway to building entrepreneurial intentions among university students. The Journal of Entrepreneurship, 30(2), 1-30. doi:10.1177/09713557211025656

Bongomin, G. O. C., Woldie, A., \& Wakibi, A. (2020). Microfinance accessibility, social cohesion and survival of women MSMEs in post-war communities in sub-Saharan Africa: lessons from Northern Uganda. Journal of Small Business and Enterprise Development, 27(5), 749-774. doi:10.1108/JSBED-12-2018-0383

Boyles, T. (2012). 21st century knowledge, skills, and abilities and entrepreneurial competencies: a model for undergraduate entrepreneurship education. Journal of Entrepreneurship Education, 15, 41-55.

Chomen, D. A. (2021). The role of microfinance institutions on poverty reduction in Ethiopia: the case of Oromia Credit and Saving Share Company at Welmera district. Future Business Journal, 7(44), 1-10. doi:10.1186/s43093-021-00082-9

Cohen, J. (1988). Statistical Power Analysis for the Behavioral Sciences: Hillsdale NJ:Lawrence Erlbaum Associates.

Dalton, P. S., Ghosal, S., \& Mani, A. (2016). Poverty and aspirations failure. The Economic Journal, 126(590), 165-188. doi:10.1111/ecoj.12210

Dorado, S. (2013). Small groups as context for institutional entrepreneurship: an exploration of the emergence of commercial microfinance in Bolivia. Organization Studies, 34(4), 533-557. doi:10.1177/0170840612470255

Economic Planning Unit (EPU). (2017). Malaysia: Sustainable Development Goals Voluntary National Review 2017. Retrieved from https://sustainabledevelopment.un.org/content/documents/15881Malaysia.pdf

Fong, E. Y., Jabor, M. K., Zulkifli, A. H., \& Hashim, M. R. (2019). Challenges faced by new entrepreneurs and suggestions how to overcome them. Paper presented at the Proceedings of the International Conference on Student and Disable Student Development 2019 (ICoSD 2019).

Gamboa, G., Mingorria, S., \& Scheidel, A. (2020). The meaning of poverty matters: trade-offs in poverty reduction programmes. Ecological Economics, 169(March 2020), 1-8. doi:10.1016/j.ecolecon.2019.106450

Gholami, R., Sulaiman, A., Ramayah, T., \& Molla, A. (2013). Senior managers' perception on green information systems (IS) adoption and environmental 
performance: results from a field survey. Information and Management, 50(7), 431438.

Gurol, Y., \& Atsan, N. (2006). Entrepreneurial characteristics amongst university students: some insights for entrepreneurship education and training in Turkey. Education and Training, 48(1), 25-38. doi:10.1108/00400910610645716

Hair, J. F., Hollingsworth, A. B., \& Randolph, A. C. (2017). An updated and expended assessment of PLS SEM in information systems research. Industrial Management \& Data Systems, 117(3), 1-41.

Hair, J. F., Hult, G. T. M., Ringle, C. M., \& Sarstedt, M. (2014). A Primer on Partial Least Squares Structural Equation Modeling (PLS-SEM): Thousand Oaks, CA: Sage Publications, Inc.

Hair, J. F., Matthews, L. M., Matthews, R. L., \& Sarstedt, M. (2017). PLS-SEM or CBSEM: updated guidelines on which method to use. International Journal of Multivariate Data Analysis 1(2), 107.

Hamid, M. S., Mohamed, S. B., \& Abdullah, A. A. (2019). Profiling of manufacturing industries bumiputera entrepreneurs (MIBE) government related agencies. International Journal of Academics Research in Business \& Social Sciences, 9(7), 1212-1262. doi:10.6007/IJARBSS/v9-i7/6240

Haque, T., Siswar, C., Ghazali, R., Said, J., \& Bhuiyan, A. B. (2021). The contribution of non-conventional Microfinancing on economic, social and household empowerment of women borrowers in Malaysia. Journal of Asian Finance, Economics and Business 8(2). doi:10.13106/jafeb.2021.vol8.no2.0643

Hatta, Z. A., \& Ali, I. (2013). Poverty reduction policies in Malaysia: Trends, strategies and challenges. Asian Culture and History, 5(2).

Henseler, J., Ringle, C. M., \& Sarstedt, M. (2015). A new criterion for assessing discriminant validity in variance-based structural equation modelling. Journal of the Academy of Marketing Science, 43(1), 115-135.

Hoque, A. S. M. M., Awang, Z., Muda, H., \& Salleh, F. (2018). Ramification of crowdfunding on Bangladeshi entrepreneur's self-efficacy. Growing Science, 4, 129-138. doi:10.5267/j.ac.2018.04.001

Hoque, N., Khan, M. A., \& Mohammad, K. D. (2015). Poverty alleviation by Zakah in a transitional economy: a small business entrepreneurial framework. Journal of Global Entrepreneurship Research, 5(1). doi:10.1186/s40497-015-0025-8

Hussain, M. D., Bhuiyan, A. B., \& Bakar, R. (2014). Entrepreneurship development and poverty alleviation: an empirical review. Journal of Asian Scientific Research, 4(10), 558-573.

Ismail, I., Rahim, N. A., Kamal, M. H. M., Mat, R. C., \& Husin, N. (2015). Investigating the needs for achievement, risk taking and tolerance for ambiguity toward 
entrepreneurial passion among single mother entrepreneur in Malaysia. Procedia Economics and Finance, 31, 110-116. doi:10.1016/S2212-5671(15)01137-5

Janjua, P. Z., \& Kamal, U. A. (2014). The role of education and health in poverty alleviation a cross country analysis. British Journal of Economics, Management \& Trade, 4(6), 896-924.

Jimenez, A., Palmero-Camara, C., Gonzalez-Santos, M. J., Gonzalez-Bernal, J., \& Jimenez-Eguizabal, J. A. (2015). The impact of educational levels on formal and informal entrepreneurship. BRQ Business Research Quarterly, 18(3), 204-212. doi:10.1016/j.brq.2015.02.002

Kamberidou, I. (2020). "Distinguished" women entrepreneurs in the digital economy and the multitasking whirlpool. Journal of Innovation and Entrepreneurship, 9(3), 226. doi:10.1186/s13731-020-0114-y

Kanayo, O., Jumare, F., \& Nancy, S. (2013). Challenges of microfinance access in Nigeria: implications for entrepreneurship development Mediterranean Journal of Social Science, 4(611-618). doi:10.5901/mjss.2013.v4n6p611

Kazeem, A. A., \& Asimiran, S. (2016). Factors affecting entrepreneurial self-efficacy of engineering students. International Journal of Academic Research in Business and Social Sciences, 6(11), 519-534. doi:10.6007/IJARBSS/v6-i11/2423

Kerr, S. P., Kerr, W. R., \& Xu, T. (2017). Personality traits of entrepreneurs: a review of recent literature. Retrieved from https://www.hbs.edu/ris/Publication\%20Files/18047_b0074a64-5428-479b-8c83-16f2a0e97eb6.pdf

Kerr, S. P., Kerr, W. R., \& Xu, T. (2018). Personality traits of entrepreneurs: a review of recent literature. Foundations and Trends in Entrepreneurship, 14(3), 279-356.

Khan, A. A., Khan, S. U., Fahad, S., Ali, M. A. S., Khan, A., \& Luo, J. (2020). Microfinance and poverty reduction: new evidence from Pakistan. International Journal of Finance \& Economics, 26(3), 4723-4733. doi:10.1002/ijfe.2038

Khan, R. U., Salamzadeh, Y., Shah, S. Z. A., \& Hussain, M. (2021). Factors affecting women entrepreneurs' success: a study of small and medium sized enterprises in emerging market of Pakistan. Journal of Innovation and Entrepreneurship, 10(11), 2-21. doi:10.21203/rs.3.rs-63473/v1

Kirkley, W. W. (2016). Creating ventures: decision factors in new venture creation. Asia Pacific Journal of Innovation and Entrepreneurship, 10(1), 151-167. doi:10.1108/APJIE-12-2016-003

Kline, R. B. (2015). Principle and Practice of Structural Equation Modelling: Guilford Publications.

Konrad, E. D. (2013). Cultural entrepreneurship: the impact of social networking on success. Creativity and Innovation Management, 22(3), 307-319. doi:10.1111/caim.12032 
Kraus, S., McDowell, W., Ribeiro-Soriano, D. E., \& Rodriguez-Garcia, M. (2021). The role of innovation and knowledge for entrepreneurship and regional development. Entrepreneurship and Regional Development, 33(3-4), 175-184. doi:10.1080/22797254.2021.1872929

Krueger, N., Linan, F., \& Nabi, G. (2013). Cultural values and entrepreneurship. Entrepreneurship \& Regional Development, 25(9-10), 703-707. doi:10.1080/08985626.2013.862961

Kusa, R., Duda, J., \& Suder, M. (2021). Explaining SME performance with fsQCA: the role of entrepreneurial orientation, entrepreneur motivation, and opportunity perception. Journal of Innovation and Knowledge, July, 1-12. doi:10.1016/j.jik.2021.06.001

Kwadzo, M. (2015). Choosing concepts and measurements of poverty: A comparison of three major poverty approaches. JOurnal of Poverty, 19(4), 409-423. doi:10.1080/10875549.2015.1015067

Lim, I. (2020). Statistics Dept: Malaysia's new poverty line income is RM2,208, over 400k households considered poor. Malay Mail. Retrieved from https://www.malaymail.com/news/malaysia/2020/07/10/statistics-dept-malaysiasnew-poverty-line-income-is-rm2208-over-400k-house/1883285

Linton, G. (2019). Innovativeness, risk-taking, and proactiveness in startups: a case study and conceptual development. Journal of Global Entrepreneurship Research, 9(20), 1-21. doi:10.1186/s40497-019-0147-5

Liu, Y., Liu, J., \& Zhou, Y. (2017). Spatio-temporal patterns of rural poverty in China and targeted poverty alleviation strategies. Journal of Rural Studies, 52, 66-75. doi:10.1016/j.jrurstud.2017.04.002

Ma'ruf, A., \& Aryani, F. (2019). Financial inclusion and achievements of sustainable development goals (SDGs) in Asean. Journal of Business and Economics Review, 4(4), 147-155. doi:10.35609/jber.2019.4.4(1)

Madanipour, A., Shucksmith, M., \& Talbot, H. (2015). Concepts of poverty and social exclusion in Europe. Local Economy: The Journal of the Local Economy Policy Unit, 30(7), 721-741. doi:10.1177/0269094215601634

Mahmood, S., Hussain, J., \& Matlay, H. Z. (2014). Optimal microfinance loan size and poverty reduction amongst female entrepreneurs in Pakistan. Journal of Small Business and Enterprise Development, 21(2), 231-249. doi:10.1108/JSBED-032014-0043

Makhbul, Z. M., \& Hasun, F. M. (2011). Entrepreneurial success: an exploratory study among entrepreneurs. International Journal of Business and Management, 6(1), 116-125. 
Mecha, N. S. (2017). Effect of microfinance on poverty reduction: a critical scrunity of theoretical literature. Global Journal of Commerce \& Management Perspective, 6(3), 16-33. doi:10.24105/gjcmp.6.3.1702

Mitchelmore, S., \& Rowley, J. (2010). Entrepreneurial competencies: a literature review and development agenda. International Journal of Entrepreneurial Behaviour \& Research, 16(2), 92-111. doi:10.1108/13552551011026995

Mohamad, N. M., Masron, T. A., \& Ibrahim, H. (2021). The role of entrepreneurship on income inequality in developing countries. JOurnal of Poverty, 25(6), 520-542. doi:10.1080/10875549.2020.1869662

Mohamad, O., Ramayah, T., Puspowarsito, H., Natalisa, D., \& Saerang, P. E. (2011). Corporate entrepreneurship and firm Performance: the role of business environment as a moderator. IUP Journal of Management Research, 10(3), 7-27.

Mohamed, E. F., \& Fauziyyah, N. E. (2020). Islamic microfinance for poverty alleviation: a systematic literature review. International Journal of Economics, Management and Accounting, 28(1), 141-163.

Mohd Nor, A. N., \& Kumar, S. (2021). The evidence of microfinance as a tool in poverty alleviation in Malaysia - a survey. Turkish Online Journal of Qualitative Inquiry, 12(6), 9673-9685.

Mohd Nor, A. N., \& Senthi, K. T. (2019). The chronology of microfinance development in Malaysia: a review. Paper presented at the FGIC 2nd Conference on Government and Integrity.

Mohd Yusof, S. W., Jabar, J., Murad, M. A., \& Ortega, R. T. (2017). Exploring the cultural determinants of entrepreneurial success: The case of Malaysia. International Journal of ADVANCED AND APPLIED SCIENCES, 4(12), 287-297. doi:10.21833/ijaas.2017.012.048

Mokhtar, S. H., \& Ashhari, Z. M. (2015). Issues and challenges of microcredit programmes in Malaysia. Asian Social Science, 11(26).

Mozumdar, L., Hagelaar, G., van der Velde, G., \& Omta, S. W. F. (2020). Determinants of the business performance of women entrepreneurs in the developing world context. Multidisciplinary Scientific Journal, 3, 215-235. doi:d oi.org/10.3390/j3020017

Mukhlisin, M., Tamanni, L., Azid, T., \& Mustafida, R. (2020). Contribution of Islamic Microfinance Studies in Achieving Sustainable Development Goals. In Elzahi Saaid Ali A., Ali K., Khaleequzzaman M. (eds) Enhancing Financial Inclusion through Islamic Finance (Vol. 1). doi:10.1007/978-3-030-39935-1_4

Noguera, M., Alvarez, C., \& Urbano, D. (2013). Socio-cultural factors and female entrepreneurship. International Entrepreneurship and Management Journal, 9, 183-197. doi:10.1007/s11365-013-0251-x 
Ong, S. Y. Y., Habidin, N. F., Salleh, M. I., \& Fuzi, N. M. (2016). Relationship of entrepreneurship practice and business performance of women Eetrepreneur in Malaysia. International Journal of Academic Research in Business and Social Sciences, 6(11), 95-109. doi:10.6007/IJARBSS/v6-i11/2376

Ota, T. (2016). Economic growth, income inequality and environment: assessing the applicability of the Kuznets hypotheses to Asia. Palgrave Communication, 3, 1-26. doi:10.1057/palcomms.2017.69

Othman, M. B. (2015). Role of women in achieving shared prosperity: an impact study of Islamic microfinance in Malaysia. Paper presented at the 2nd Global Conference on Business and Social Science.

Podsakoff, P. M., MacKenzie, S. B., Lee, J. Y., \& Podsakoff, N. P. (2003). Common method biases in behavioral research: a critical review of the literature and recommended remedies. Journal of Applied Psychology, 88(5), 879-903. Retrieved from http://www.ncbi.nlm.nih.gov/pubmed/14516251

Polas, M. R. H., Raju, V., Muhibbulah, M., \& Tabash, M. I. (2021). Rural women characteristics and sustainable entrepreneurial intention: a road to economic growth in Bangladesh. Journal of Enterprising Communities: People and Places in the Global Economy. doi:10.1108/JEC-10-2020-0183

Ringle, C. M., Wende, S., \& Becker, J.-M. (2015). SmartPLS 3. Retrieved from www.smartpls.com

Sadri, A. (2010). Science-driven entrepreneurship in the Islamic world. International Journal of Information Science and Management, 8(1), 73-81.

Sambharya, R., \& Mustteen, M. (2014). Institutional environment and entrepreneurship: an empirical study across countries. Journal of International Entrepreneurship, 12(4), 314-330. doi:10.1007/s10843-014-0137-1

Samson, A. Y., Olubunmi, A. B., \& Olusegub, A. A. (2013). Microfinance bank as a catalyst for entrepreneurship development in Nigeria:

evidence from Ogun State. International Journal of Business and Social Science, 14(12), 286-303.

Sanchez, J. C. (2013). The impact of an entrepreneurship education program on entrepreneurial competencies and

intention. Journal of Small Business Management, 51(3), 447-465. doi:10.1111/jsbm.12025

Sekaran, U. (2003). Research method for business: A skill building approach. United States: John Wiley \& Sons.

Selvaraj, T., Karim, Z. A., Abdul-Rahman, A., \& Chamhuri, N. (2018). The effects of microcredit access and macroeconomic conditions on lower income group. International Journal of Economics and Management, 12(1), 285-304. 
Shah, H., \& Saurabh, P. (2015). Women entrepreneurs in developing nations: growth and replication strategies and their impact on poverty alleviation. Technology Innovation Management Review, 5(8), 34-43. doi:10.22215/timreview/921

Shaheen, I., Hussain, I., \& Mujtaba, G. (2018). Role of microfinance in economic empowerment of women in Lahore, Pakistan: a study of akhuwat supported women clients. International Journal of Economics and Financial Issues, 8(2), 337-343.

Shahzad, M. F., Khan, K. I., Saleem, S., \& Rashid, T. (2021). What factors affect the entrepreneurial intention to start-ups? the role of entrepreneurial skills, propensity to take risks, and innovativeness in open business models. Journal of Open Innovation: Technology, Market, and Complexity, 7(3), 1-23. doi:10.3390/joitmc7030173

Shaikh, S. (2020). Challenges faced by women owned micro, small and medium enterprises in an emerging economy. International Journal of Management, 11(7). doi:10.34218/IJM.11.7.2020.135

Sharma, M., Guptu, M., Sharma, R. L., \& Sharma, A. K. (2021). Prospects and challenges of microfinance as a tool in poverty reduction. Academy of Marketing Studies, 25(6), 1-6.

Shastri, S., \& Sinha, A. (2010). The socio-cultural and economic effect on the development of women entrepreneurs (with special reference to India) Asian Journal of Business Management, 2(2), 30-34.

Si, S., Ahlstrom, D., Wei, J., \& Cullen, J. (2019). Business, entrepreneurship and innovation toward poverty reduction. Entrepreneurship \& Regional Development: An International Journal, 32, 1-20.

Siti-Nabiha, A. K., \& Siti-Nazirah, A. Z. (2021). Performance measurement in Islamic microfinance institutions: does it change social norms and values? Qualitative Research in Financial Markets. doi:10.1108/QRFM-09-2020-0186

Sutter, C. (2019). Entrepreneurship as a solution to extreme poverty: a review and future research directions. Journal of Business Venturing, 34(1), 197-214. doi:10.1016/j.jbusvent.2018.06.003

Tadesse, D. A. (2020). Factors affecting women entrepreneurs in establishing their own business: the case of Afar Region, Ethiopia. African Journal of Business Management, 14(3), 86-92. doi:10.5897/ajbm2019.8919

Tentama, F., \& Dahlan, F. (2020). Internal locus of control and entrepreneurial intention: a study on vocational high school students. Journal of Education and Learning, 14(1), 97-102. doi:10.11591/edulearn.v14i1.13999

Ussif, R. (2020). Microfinance institutions challenges in poverty and unemployment reduction in Ghana International Journal of Engineering and Information Systems, 4(7), 114-123. 
Wasdani, K. P., \& Mathew, M. (2014). Potential for opportunity recognition along the stages of entrepreneurship. Journal of Global Entrepreneurship Research, 2(7), 124. doi:10.1186/2251-7316-2-7

World Bank Group. (2020). Malaysia Economic Monitor: Sowing the Seeds. Retrieved from

https://openknowledge.worldbank.org/handle/10986/34929\#: :text=Malaysia\%20 Economic\%20Monitor\%2C\%20December\%202020\%20\%3A\%20Sowing\%20the $\% 20$ Seeds,-

cb\&text=Malaysia's\%20economy\%20is\%20projected \%20to,by\%205.8\%20percen t\%20in\%202020.\&text=Notwithstanding\%20a\%20growth\%20rebound\%20in,wit hin\%20the\%20next\%20few\%20years.

Xheneti, M., Karki, S. T., \& Madden, A. (2019). Negotiating business and family demands within a patriarchal society - the case of women entrepreneurs in the Nepalese context. Entrepreneurship \& Regional Development, 31(3-4), 259-278. doi:10.1080/08985626.2018.1551792

Yang, M. (2013). Entrepreneurial competencies of women entrepreneurs pursuing business growth. Journal of Small Business and Enterprise Development, 20(1), 125-142. doi:10.1108/14626001311298448

Yang, Y., \& Liu, Y. (2021). The code of targeted poverty alleviation in China: a geography perspective. Geograpghy and Sustainability, 2(4), 243-253. doi:10.1016/j.geosus.2021.09.004

Yang, Y., Sherbinin, A. d., \& Lu, Y. (2020). China's poverty alleviation resettlement: progress, problems and solutions. Habitat International, 98(April 2020). doi:10.1016/j.habitatint.2020.102135 